\title{
Ghosts and Shadows: A History of Racism in Canada
}

\author{
Maureen Kihika \\ Simon Fraser University, Department of Sociology and Anthropology
}

A history of racism reinforces discrimination and exploitation of racialized immigrants in general and African-Canadians in particular. My paper contends that historically institutionalized structures are the ideological fulcrum from which ongoing socio-economic inequalities derive and retain their legitimacy. Specifically, I argue that the historically institutionalized system of slavery and ensuing systemic structures of racial discrimination negatively influence the incorporation of racialized immigrants into the Canadian labour market. A historically racially segmented labour market continues to uphold colour coded social and economic hierarchies. Although Canada's point system ensures that immigrants are primarily selected on the basis of their skills and qualifications, many professionally trained and experienced racialized immigrants endure perpetual socio-economic constraints, characterized primarily by low-end, precarious forms of employment. While not intended to serve as an exhaustive chronology, this essay draws on three historical periods of Black migration and experience in Canada: the first spans early sixteenth to the end of the eighteenth-century, the second dates from the nineteenth to mid-twentieth century, and the third extends from mid-twentieth century to the present. The following historical timeline traces the prevalence and enduring nature of systemic structures and substantiates Abigail Bakan's (2008) suggestion that both "racism and a culture of hegemonic whiteness were and remain endemic to the Canadian state" (p. 6).

Keywords: Black history in Canada; systemic structures; labour market segmentation; racial discrimination

Une histoire du racisme appuie le constat de la discrimination et de l'exploitation d'immigrants appartenant à des groupes raciaux en général et de Canadiens africains en particulier. Mon essai soutient que les structures historiquement institutionnalisées constituent le point de départ des inégalités socioéconomiques actuelles et prolongent leur légitimité. Plus précisément, je prétends que le système d'esclavage historiquement institutionnalisé et les structures systémiques de discrimination raciale qui en ont découlé ont nui à l'intégration sur le marché du travail canadien des immigrants appartenant à des groupes raciaux. Un marché du travail depuis toujours segmenté racialement renforce encore la hiérarchie économique et sociale fondée sur la couleur. Même si le système de points d'appréciation canadien fait en sorte que les immigrants sont choisis essentiellement sur la base de leur formation et de leurs compétences, de nombreux immigrants membres de groupes raciaux disposant d'une formation et d'une expérience professionnelles subissent de perpétuelles restrictions socioéconomiques, comme des emplois bas de gamme ou précaires. Cet essai ne prétend pas être une chronologie exhaustive, mais il décrit trois périodes historiques de la migration des Noirs et de leur expérience au Canada : la première époque s'étend du début du XVIe siècle à la fin du XVIIIe siècle, la deuxième du XIXe siècle au milieu du XXe siècle et la troisième, du milieu du XXe siècle à maintenant. Cette chronologie témoigne de la prévalence et de la persistance des structures systémiques et appuie la suggestion d'Abigail Bakan (2008) selon laquelle "le racisme et une culture dominante blanche ont été et demeurent endémiques dans l'État canadien » (p. 6) [traduction libre].

Mots-clés : Histoire des Noirs au Canada; structures systémiques; segmentation du marché du travail; discrimination raciale 


\section{Introduction}

...just as the battle against slavery was being won by abolitionists, the war against racism was being lost. The Negro was legally freed by the Emancipation Act of 1833, but in the British mind he was still mentally, morally and physically a slave (Stepan, as cited in Alexander \& Glaze, 1996, p. 37).

This paper argues that the socio-economic marginalization of Black African immigrants in Canada can be attributed to the pervasiveness of historically prejudicial racial constructed categories. I employ an anti-racist theoretical framework to illustrate how the peripheral socio-economic locations occupied by Black people have long been shaped by the intersection of complex racialized, classed and gendered processes. This historical analysis is inspired by the prolific writings of authors such as Clairmont \& Magill (1970), Tulloch (1975),Walker (1980), and Winks (1971; 1997) From this canon, narratives of African-Canadian experiences provide an invaluable opportunity to reflect on a people whose history, while mostly forgotten, lingers on as a significant determinant of individual prospects and social mobility. This essay is also motivated by the more recent literary work and critical scholarship of social science writers such as Abdi (2005), Bakan (2008), Cooper (2006), Creese (2011), Galabuzi (2006), Mensah (2010) and Tettey \& Puplampu (2006) who persistently call attention to the growing social exclusion of racialized groups in Canada.

Findings in this analysis indicate that the structure of slavery, the legacy of racism, and the current processes of labour market de-regulation, reinforce deteriorating socio-economic circumstances for many racialized people. In other words, this essay attempts to establish a link between the old problems of imperialism and the emerging realities of racialized poverty, which I argue, continue to be shaped by neoliberal policies that increasingly normalize racialized labour markets in industries such as the service sector. Specifically, global neoliberal economic re-structuring practices, enshrined in privatization and deregulation policies within the areas of social reproductive provisioning such as child and elderly care, reveal intensified processes of racialization and feminization. This can be exemplified through state institutions such as Canada's federally enacted Live-in Caregiver Program (LCP) - an immigration policy - which solicits racialized immigrant women for exploitative reproductive service work, whereby racialized foreign women provide the 'arduous labour of love' as care-takers and housekeepers in middle class Canadian homes and other home-care facilities. Given that the LCP immigration program is validated on the premise that these low status occupations are considered impossible to fill without foreign workers, the role of institutionalized state practices in providing and subsidizing the labour of immigrant women thereby reinforcing its devaluation is significantly worth mentioning.

It is hoped that this research will add to voices that have sought to tell of the history of Blacks in Canada that has largely been suppressed (see Compton, 2010; Cooper, 2006; Nelson, 2002; and, Winks, 1971) and in so doing, recuperate the agency of blackness. Throughout the following discussion, the concepts of 'racialized immigrants' and 'visible minorities' are used interchangeably to refer to those populations that were officially recognized as such, as defined in the Royal Commission Report on Equality and Employment in 1984 which led to the Employment Equity Act of 1986.

\section{Historical Background of Blacks in Canada}

In The Blacks in Canada: A History, Robin Winks (1971) sets out to tell the story of Blacks-as settlers and transients - which, as he notes, has never been told in any satisfactory manner. Although Blacks, owing to slavery, were among the first non-indigenous residents of Canada, settling before the middle of the seventeenth-century, Winks points out that Canadian historians have generally not recognized the Black experience or how this is significant for the past and present. At best, such partial accounts distort collective consciousness, as they overstate certain histories (e.g. Canada's role as a place of refuge for formerly enslaved Africans), while making invisible the organized resilience of racialized Blacks. At worst, this misrepresentation completely obscures the active role of racialized people in the construction 
of the Canadian state and disparages the agency demonstrated in their sustained political and social resistance against oppression.

Justifiably, the lack of a plantation economy may facilitate a misreading of Canada as a raceneutral space, supporting the sociocultural myth that the country was a place of refuge for enslaved Blacks coming from America and subsequently from Jamaica. That being said, although the practice of slavery in Canada was not as extensive as that in the United States or in the Caribbean, it was not, as those who have attempted to dismiss it claim, any 'milder' or 'easier' for those affected. Certainly, because agriculture has historically been of secondary economic importance due to the country's geographical positioning and unsuitable climatic conditions, the extent of slavery in Canada does not warrant the image of a huge cotton or sugar plantation worked by hundreds of slaves, drenched in blood and sweat as they endured constant whipping from the slave-drivers (Cooper, 2006). Nevertheless, Canada was a society that exploited the labour of formerly enslaved Africans.

Slavery was, Cooper explains, a legal and acceptable institution in both French and English Canada and was practiced extensively from 1628 to 1833. In New France, modern day Quebec, and later in British Canada for example, slaves were the property of a variety of individuals and corporations such as the Catholic Church, the nobility, lawyers, government officials, farmers, business people, soldiers and merchants. Among other responsibilities, it is commonly known that slaves worked in the farmland, as domestics, fixing women's hair, milking cows, and feeding chickens (Cooper, 2006). Enslaved Black women were also used as breeders to increase the slave population. While Aboriginal people, Africans, and their descendants were enslaved, Blacks were considered sturdier and appeared better able to withstand the physical demands of slavery: their average age of death was 25.2 years, compared to 17.7 years for Aboriginals (Cooper, 2006).

As French colonists settled and expanded their colonizing ventures in Canada, more Black slaves were brought in as the available labour force could not meet the demands created by the burgeoning economy (Abdi, 2005). This labour infusion was critical for the economic well-being of places such as Ontario, Quebec, and the Atlantic Provinces, namely New Brunswick and Nova Scotia. Specifically, Black slaves were considered integral for the construction and building of major trading centers such as Halifax, which ironically became a leading center for the public auction of enslaved Blacks. Indeed, at this time, the sale of slaves was a feature of life in Canada, with the value of the slave property dependent on physical health, special aptitudes, age, sex, and other factors (Cooper, 2006).

Olivier Le Jeune, the first recorded Black slave - a nine year old boy from Madagascar - was, for example, sold for 50 livres in 1628. Marie-Joseph Angelique, the twenty-nine year old Portuguese-born Black slave woman who was tortured and hanged in 1734 had been sold for a barrel of gunpowder. Advertisements such as one depicting a certain Mr. Prenties who wanted to sell a Negro woman, who had with her a mixed race - or as was commonly referred to in those days 'mulatto' - child of 9 months old, is believed to have brought in a good price of up to 30 to 50 livres (Quebec Gazette February 23, 1769, as cited in Cooper, 2006). It is worth noting that the price of this slave woman with a child was higher because children born to slave-women, like their mothers, automatically became the property of the slaveholder. Also, the fact that this Black woman had with her a mixed-race child tells of a possible sexually abusive affair between a slave woman and her slave owner. As these examples unequivocally illustrate, presumptions that seek to portray Canada as a benevolent 'protector' of suffering Black 'slaves' from the United States and elsewhere are misplaced and deeply patronizing.

The widespread neglect of Black history produces, reproduces, and perpetuates stereotypical characterizations of Black people as invisible, dependent, and unskilled. For example, older Black women embodying the 'black mammy' stereotype, based on the service work that they are structurally confined to, are considered fitting for the unskilled labour of providing 'care' for others as maids or domestic service workers. Stereotyped as lazy, incompetent, aggressive and criminals, Black men on the other hand are considered unemployable social misfits. Disregarding the history of Black Canadian experience serves to facilitate racism under the guise of 'anti-racism' for which 'the outcome can only be further efforts to marginalize people from participation in political, social, and cultural concerns that affect the entire society" (Saney, 1998, p. 78). Although race is now widely perceived to be a socially constructed and 
changing set of social relations, it remains a Canadian-made reality and is often drawn upon to apportion rewards and privileges in social and economic status. For instance, non-racialized populations continue to be overrepresented in the primary labour market where they occupy secure professionalized positions and enjoy increased monetary and status rewards. Race-ism, the systemic and structural processes through which certain populations are marginalized, excluded, and disadvantaged based on physical categorizations and socially constructed ideologies, while scientifically unfounded 'feels,' in Bakan's (2008) words, to be 'meaningful,' thus sustaining the status quo. Race and racism therefore provide a coherent and institutionally supported systemization of who is imagined as part of a collective citizenry and who is excluded.

\section{First Historical Period}

The first historical period of slavery spanned the early sixteenth to the end of the eighteenth century. During this time, the first wave of Blacks comprised of servants, slaves, and indentured labourers, arrived in Canada. Although Olivier Le Jeune, the young boy from Mozambique, is believed to have been the first African to have been transported directly from Africa and sold as a slave in New France, the arrival of Matthew Da Costa in Nova Scotia in 1606 is considered to be the root of Black history in Canada (James, Este, Bernard, Benjamin, Lloyd \& Turner, 2010). From the end of the seventeenth through to the eighteenth century, acute labour shortages prompted the importation of Blacks in significant numbers (Abdi, 2005; Mensah, 2010). The prosperity of the New England colonies was, for example, historically attributed to the prevalence of Black slave labour which in turn led to the demand for increased importation of enslaved labour.

Notably, although slavery had been abolished in France in the period between the seventeenth and nineteenth century, Jean Talon - the first administrative official of New France - persuaded King Louis XIV to permit the continued importation of Black slaves. As a result, the slave system was given full legal backing in New France, modern-day Quebec, and by 1709, nearly all respectable members of society depended on the labour of chattel slaves. As legal reinforcement, the New France militia was used to assist slave owners in retrieving runaway slaves, thus bringing the power of the state to bear in the enforcement of servitude. Slavery continued in Quebec even after the 1759 conquest that brought the region under British control. The $47^{\text {th }}$ article of capitulation, signed after the fall of Montreal in 1760, not only guaranteed the widespread continuation of this oppressive system in British Quebec but also in other parts of the colony such as in the Maritime Provinces (Boyko, 1998; Cooper, 2006; James et al., 2010).

Although the first group of enslaved Blacks arrived to Canada in significant numbers in the 1750s, around the beginning of the American Revolution, their numbers are believed to have increased with the arrival of White Loyalists who were accompanied by their slaves. Similarly, there was also a wave of Black Loyalists who ran away from their masters to fight on the side of the British during the American War of Independence in exchange for the promise of land and wages (James et al., 2010). With the hope that their fighting would be instrumental in the delivery of their own freedom and the ultimate abolition of slavery, Blacks served as soldiers, general labourers, spies, entertainers, and domestic workers.

In the end, the promises of treatment equal to that of their White military comrades that were made to Black Loyalists in exchange for their services and sacrifices never materialized. Rather, Black slaves who had risked their lives and those of their families to escape horrifying cruelty in the American South were seen as people that could be easily manipulated and treated like stray animals neither to be returned to their owners in the South, nor welcomed as genuinely free and equal citizens in the North. For example, the British pledge of one-hundred-acre land grants to Blacks in places like Halifax, Nova Scotia, resulted in much smaller acreages filled with scrub and other non-arable margins rejected by White settlers (Alexander \& Glaze, 1996; Galabuzi, 2006). Despite the pledge, about 60 percent of formerly enslaved and freed Blacks that had been promised full citizenship rights in Canada received no land whatsoever (Lampkin, 1985).

In comparison, White Loyalists were not only granted their preferential choices of land location but were also awarded land ranging from 15 to 150 acres (Boyko, 1998). Evidently, the privileging of land 
grants was influenced by the prejudicial power of race rooted in and normalized throughout history. The discrimination of Blacks was not isolated to land but extended elsewhere such as in the proposal to surrender Black Loyalists as ransom for British prisoners held by Americans (Mensah, 2010). Black people were never welcomed as genuinely free and equal citizens in Canada but were viewed as legal property and easily disposable commodities. While the exclusion of Blacks was overt and standard practice in the sixteenth to eighteenth centuries, salient exclusionary practices in social, economic, and political spheres exist to date and continue to reinforce the historical marginalization of Black people in Canada.

Embedded in historically hegemonic ideologies, perceptions that historically portray Blacks as cheap and an expendable labour force perpetuate oppressive stereotypes and can further foster internalized racism which can be as destructive, if not more, as external forms of racial oppression. As James Walker's Racial Discrimination in Canada: The Black Experience (1985) surmises, “... traditions established in slavery have resulted in a prescribed economic position for blacks ... as reflected in their social status ... fixed to the lowest level of the hierarchy" (cited in Alexander \& Glaze, 1996, p. 34). Today, it is troubling that many African-Canadians are either unemployed or underemployed. Quintessentially, while almost all Africans in Canada can speak either one or both of Canada's official languages and are reported to be more likely to have university degrees (19\% compared with $15 \%$ of the overall adult population), they are nonetheless more likely to be unemployed (Statistics Canada, 2001).

\section{Second Historical Period}

From the nineteenth to the mid-twentieth century, the second significant wave of Blacks entered Canada through the Underground Railroad. While no official data are available on the number of Black fugitives crossing into Canada, the Underground Railroad is declared a highly effective means by which many fugitive slaves reached British North America. Although enslaved Africans running from the American South were known to fight their oppressors by 'rebelling,' the Underground Railroad was an important means by which Blacks, as central agents of their own freedom struggle, resisted oppression (Bakan, 2008). The North Star, Bakan writes, remained the sole reference on the unwritten maps that fugitive slaves followed on their entire journey from the south to the north. In solidarity and camaraderie, abolitionists - free men and women, Black and White alike - risked their lives to stand beside fugitive slaves seeking refuge on British colonial soil. The assisted entry into Canada of fugitive slaves has been credited to organizations such as the Pennsylvania Society for Promoting the Abolition of Slavery, the Quakers, and the American Baptist Free Mission Society (Abdi, 2005). On an individual level, Harriet Tubman, the woman dubbed 'Black Moses' was instrumental in arranging for the movement of people and is known to have provided accommodation to some of the refugees in St. Catharine's, Ontario (Abdi, 2005; Boyko, 1998; Mensah, 2010). Other individuals included Alexander Ross, a White doctor from Ontario, who under the guise of studying birds, often travelled to the southern plantations to help slaves plan their escape by providing provisions and information on secret routes (Alexander \& Glaze, 1996).

Additional instrumental 'conductors' of the Underground Railroad included Calvin Fairbanks who was imprisoned for freeing 1,300 slaves; Frederick Douglass, considered one of Black America's most influential abolitionists; Levi Coffin and William Still, the 'presidents' of the Underground Railroad. Other notable abolitionists included but were not limited to: Mary Shad, the first Black woman on the North American continent to found and edit a weekly newspaper, The Provincial Freeman, that called for slaves to escape to Canada, and John Brown, the White abolitionist who was tried for treason and hanged and has since remained a martyred symbol of the heroic fight against slavery (Bakan, 2008).

The Underground Railroad has therefore since been considered a defining moment in the making of Canada. It has given Canada a proud but nonetheless disingenuous reputation as a nation whose origin and early history is consistent with modern philosophical ideals of inclusivity and multiculturalism. However, in her analysis of the role of the Underground Railroad in the making of the Canadian state, Abigail Bakan pertinently challenges the widely-held but factually-inconsistent view of Canada as an anti-racist, anti-imperialist space. By disputing the morality of slavery, Bakan clarifies, Canadian ruling 
classes' opposition to the encroachment of US capitalism appears as less an altruistic motivation and more a means to "secure a defined market for a specifically Canadian capitalist and imperialist accumulation project" ( 2008 , p. 6). Simply put, enslaved fugitives were only considered safe in British North American colonies as a result of Canada's strategic political and economic advancements, intended to secure a defined market for a capitalist and imperialist project. It was not, as common discourse stipulates, the outcome of Canada's anti-racist and anti-imperialist stance. As such, Canada's appearance as a place of refuge for runaway slaves was the product of politico-economic considerations that were intended to advance the country as a capitalist competitor. The industrial ruling class in British North American colonies tactfully and paradoxically used colonialism and anti-colonialism as contesting strategies by which they could expand and broaden their capitalist reach.

Transitioning from an empire-based monopoly trade and slave plantation labour concentrated in the Americas, British colonialism moved to a more productive and competitive phase of industrial capitalism premised on the concept of 'free' waged labour. The exploitation of waged labour was alluringly more profitable for imperialist industrial capital. Consequently, the British North America that was to be the 'promised land' of liberated slaves instead became a disputed space of classed and racialized interests. Canada's transformation from a place that had vowed freedom and liberty for all, to a contested space organized around race and class ideologies made presumptive claims about the country's opposition to racism and slavery as an institution both ironic and insincere. Although there was some physical freedom that accompanied the slaves' escape to Canada, their full socio-economic and political rights did not materialize. Far from enjoying the rights and freedoms of a 'promised land,' emancipated slaves in Canada experienced discrimination which purportedly progressively worsened until there were widespread complaints of prejudicial experiences by the Blacks in Canada as had been for those in the United States. For example, Blacks faced segregated schools, restaurants, and theatres in Canada, as in the United States. Moreover, many Canadian counties made it illegal for Black people to run for office, sit in juries, purchase land or own business licenses. Hence, despite civil freedom in Canada, most refugees discovered upon arrival that they had exchanged one kind of insecurity for another. Owing to racism, poverty, and the notion of 'freedom promised but not fulfilled,' many Blacks returned to the US after the American Civil War and the Lincoln Emancipation Proclamation of 1863 (Bakan, 2008 and Mensah, 2010).

Of the former slaves who stayed, many settled in central and eastern Canada, especially Ontario, Quebec, and Nova Scotia, while some from the western US settled in the Prairie provinces and British Columbia. Not surprisingly, many of these provinces retained sociocultural and political acceptance of dehumanizing acts against Blacks. In particular, the Prairie governments, business establishments, and ordinary citizens were doing all they could to frustrate the existing Black communities and to prevent the influx of additional Blacks into the region. A case in point was Bruce Walker, the Commissioner of Immigration in Winnipeg, who admitted that the Canadian government was "doing all in its power through a policy of persuasion, to bar Blacks from Canada upon the broad ground of being undesirables" (Winks, 1997, p. 311). In a similar vein, efforts to frustrate and prevent the entry of Blacks into Canada evidenced through the resolutions passed by Boards of Trade in almost all Prairie towns and cities, essentially demanding the curtailment of Black immigration between 1901 and 1911 are noteworthy (Boyko, 1998). While some resolutions called for strict segregation, others went as far as demanding the immediate deportation of Blacks. The height of intolerance towards Blacks was particularly demonstrable when Blacks were all together banned from the Edmonton City Council in 1911 (Boyko, 1998). Given these harsh realities, any implicit suggestions to sanitize the suffering of Black experience in Canada (visà-vis the United States) are distasteful, as they minimize the human indignities of slavery, and fail to acknowledge that Black experiences in Canada included legalized segregation.

\section{Third Historical Period}

The third wave of Black migration to Canada began from the mid-1960s and continues to the present. Until the 1960s, the Canadian government, determined to maintain an imagined White community 
preferred 'desirable' White immigrants, specifically those from Western Europe and the United States. Meanwhile, access was barred through exclusionary immigration policies for those considered 'less desirable' and 'undesirable'. The conventional wisdom in pre-1960s Canada was that Blacks in particular were physically, mentally, and morally inferior to Whites that their influx would potentially create social, cultural and political economic tensions between the races (Mensah, 2010). Furthermore, owing to similar racist concerns that characterized pre-World War II immigration policy, Black people were considered as both lacking the potential to assimilate into a fast-paced, competitive, capitalist society and were viewed to be woefully unsuited for Canada's climatic conditions (James et al., 2010; Satzewich \& Liodakis, 2007).

The need to recruit skilled workers for the Canadian labour market, and to also address historically embarrassing episodes in the treatment of Black and other 'less desirables' led Canadian immigration, through the introduction of the point system in 1967, to purportedly treat and admit equally skilled professionals. Using the point system, prospective immigrants, irrespective of country of origin, race, or ethnic background, are evaluated on the basis of variables such as age, education, and occupational demands. To this end, the 2006 Census estimated that 5,068,100 individuals belonged to a visible minority group, a figure which accounted for $16.2 \%$ of Canada's total population, up from $13.4 \%$ in 2001 and $11.2 \%$ in 1996. According to recent Census estimates, nearly 1 in 5 Canadians are foreign born - the highest proportion since 1931 - with 200,000 to 300,000 new immigrants arriving in Canada yearly (Statistics Canada, 2008, p. 5). From these, South Asians were the largest visible minority group while Chinese and Blacks, respectively, counted as the second and third largest visible minority groups.

Within the ethno-cultural diversity in Canada, the Black population is representative of a relatively small but rising population. The rising growth is evidenced by records indicating that while the number of Blacks in 1961 was noted at 32,100 (0.2\% of the population), it grew to 34,400 in 1971 , later increasing to $239,500(1 \%)$ in 1981. By 1991, Blacks were numbered at 504,300 (1.9\%) and 10 years later, their number was recorded to have risen up to 662,200 (2.2\%) (Statistics Canada, 2001). Overall, during the 1970s, Black Canadians accounted for 5.8\% of all immigrants (Opoku-Dapaar, 2006, p. 69 as cited in Creese, 2011, p. 20). This statistic climbed to $10.6 \%$ of all newcomers in the period from 2001 to 2006 (Statistics Canada 2007, p. 11).

Despite their growing numbers, however, Blacks immigrants in Canada are increasingly marginalized in terms of job opportunities, income, and occupational status. In particular, the number of Blacks in more secure forms of employment such as that within the primary labour market, where labour is defined as central to the formal economy (e.g. professionalized managerial work), is unrepresentative of the overall Black population. Rather, Blacks are overrepresented in the types of employment that are considered peripheral to the formal economy (e.g. care-related service occupations that are often characterized by little legislative protections and exploitative conditions). For example, only $7 \%$ of employed African-Canadians held management positions, compared with $10 \%$ of the overall labour force (Statistics Canada, 2001, p. 14). Black African immigrant labour force participants tend to be overrepresented in lower paying, contractual and 'flexibilized' work, generally categorized within the service sector. The occupations in this segment feature health care, manufacturing, and sales. As of 2001, statistics enumerated that $7 \%$ of all employed African-Canadians worked in the health sector, whereas this was the case for only $5 \%$ of all Canadian employees. At the same time, $10 \%$ of workers of African origin, versus $8 \%$ of the total Canadian workforce were employed in manufacturing jobs, while $26 \%$ of African workers compared with $24 \%$ of the overall workforce worked in sales or service jobs (Statistics Canada, 2001, p. 14).

Incomes of employed Africans were also reported to be considerably lower than those of the rest of the population. In 2000 for instance, African immigrants 15 years and over were assessed as having had an average income just under $\$ 24,000$, about $\$ 6,000$ less than the national figure. As a result of the relatively large proportion of low income earners among Africans, 39\% had incomes considered to be below the official low-income cut-offs compared with $16 \%$ of the overall Canadian population (Statistics Canada, 2001).While migration remains a reflection of global diversity, these statistics alarmingly 
indicate that in Canada, one's national and racial(ized) background continues to affect social mobility and quality of life.

Galabuzi (2006) suggests that neo-liberal economic restructuring practices have intensified processes of racialization, feminization, and sexism in the labour markets. As he argues, changes in liberal welfare economic markets have potentially led to increased economic, social, and political inequality of vulnerable men, women, and children. In Arat-Koc's (2006) and Calliste's (2000) discussions on social reproductive work for example, economic restructuring processes have created further differences between women as (predominantly white) middle-class women in the West buy and constantly depend on the backbreaking work of immigrant women who (as previously mentioned in this essay), migrate as domestics and care-takers. Such patterns of economic restructuring reinforce the increase particularly of racialized women in gendered spaces. Thus, global economic restructuring has not only encouraged the informalization of economies and 'precarious work,' but has also "exacerbated previous fissures of racial inequality based on systemic discrimination" (Galabuzi, 2006, p. 10). Consequently, although legal racism and forced exclusion has been neutralized, African-Canadians continue to face systemic and institutional discrimination that is subtle in form, but constraining in effect (Laryea \& Hayfron, 2006).

\section{Conclusion}

As this paper argues, the historic development of Canadian capitalist economy and society laid the foundation for the policies of slavery and labour market processes that encourage the persistence of highly deleterious terms of socio-economic incorporation of Blacks, as well as other racialized immigrants. Fundamentally, the historical structures of racial discrimination influence the incorporation of racialized immigrants into the Canadian labour market, leading to a labour market hierarchy that is stratified along colour codes (Porter, 1965). In earlier periods of immigration, despite their qualifications, potential immigrants who were considered 'less desirable' could only work within other people's households, or as manual laborers in fields, factories and transportation industries.

Specifically, during the sixteenth to the end of the eighteenth century, at the time of their first historical migration to Canada for instance, Blacks in places such as Quebec and Nova Scotia were limited to working as soldiers, general labourers, spies, entertainers, and domestic workers. Following this, in the period between nineteenth to the mid-twentieth century, when the second significant wave of Blacks entered Canada through the Underground Railroad, increased reports on exploitation and prejudice experienced by Blacks persisted, despite the perception that these fugitives were entering the 'promised land'. In this period, many Canadian counties and cities such as Winnipeg made it illegal for Black people to run for office, sit in juries, purchase land or own business licenses. While immigration policy reforms during the third wave of Black migration to Canada, beginning from the mid-1960s to the present, are considered more tolerant through their facilitation of larger numbers of racialized immigrants, Blacks in Canada continue to be marginalized in terms of job opportunities, income, and occupational status. Specifically, the numbers of Blacks in more secure forms of employment remains minimal and unrepresentative of the overall Black population. Instead, Blacks continue to be overrepresented in the types of employment that are considered peripheral to the formal economy (e.g. care-related service occupations that are often characterized by little legislative protections and exploitative conditions).

In the present time, Blacks, along with other racialized immigrants, mostly selected on the basis of their skills and qualifications, are positioned at a level within the social structure that "peripheralizes' them and constrains their capacity for structural transformation" (Tettey \& Puplampu, 2006, p. 14). Often, they end up in sectors with largely casualized employment and low-end jobs. Indeed, as John Porter aptly affirmed, "the Canadian terrain is still, overall, rife with situations where ethnic and racial considerations determine employment and the concomitant advancements that result from it" (Cited in Abdi 2005, p. 56). The persistence of racial biases and discrimination as experienced by Blacks in Canada highlights the enduring influence of an institutionalized system of slavery and systemic racism. Although absolute slavery is arguably no longer practiced in Canada, the effects of institutionalized racism where Blacks are 
perceived as an incompetent, inferior, and exploitable labour force lingers on in subtle, but not any less meaningful ways. Recognizing the persistence of historically institutionalized systems of slavery and racism, and acknowledging the Black experience, are crucial starting points in fostering a meaningful post-racial society.

About the Author: Maureen Kihika is a Ph.D. student in the Department of Sociology and Anthropology at Simon Fraser University. Her research interests are in the areas of neo-liberal restructuring processes and the privatization of social reproductive work, particularly in how they affect African immigrant women within the Canadian capitalist economy. She can be reached at: mkihika@sfu.ca

\section{References}

Abdi, A. (2006). 'Reflections on the Long Struggle for Inclusion: The Experiences of People of African Origin' In Tettey, J. \& Puplampu, K. (Eds.), The African Diaspora in Canada: Negotiating Identity and Belonging. (pp. 49-60). Calgary: University of Calgary Press.

Alexander, K. \& Glaze, A. (1996). Towards Freedom: The African-Canadian Experience. Toronto: Umbrella Press.

Arat-Koc, S. (2006). 'Transnational Motherhood and Feminist Political Economy' In Bezanson, K. \& Luxton, M. (Eds.), Social Reproduction: Feminist Political Economy Challenges Neoliberalism. (pp.173-214). Montreal and Kingston: McGill-Queen's University Press.

Bakan, A. (2008). 'Reconsidering the Underground Railroad: Slavery and Racialization in the Making of the Canadian State'. Socialist Studies 4 (1) 3-29.

Boyko, J. (1998). Last Steps to Freedom: The Evolution of Canadian Racism. Toronto: J. Gordon Shillingford.

Calliste, A. (2000). 'Nurses and Porters: Racism, Sexism and Resistance in Segmented Labour Markets' In Calliste, A. \& Dei, S. G. (Eds.), Anti-Racist Feminism: Critical Race and Gender Studies. (pp. 143-163). Halifax: Fernwood Publishing.

Clairmont, D. \& Magill, D.H. (1970). Nova Scotian Blacks: An Historical and Structural Overview. Halifax: Institute of Public Affairs, Dalhousie University.

Cooper, A. (2006). The Hanging of Angelique: Canada, Slavery and the Burning of Montreal. Toronto: Harper Collins.

Creese, G. (2011). The New African Diaspora in Vancouver: Migration, Exclusion and Belonging. Toronto: University of Toronto Press.

Das Gupta, T. (2009). Real Nurses and Others: Racism in Nursing. Halifax: Fernwood Publishing.

Este, C. D. (2008). 'Black Canadian Historical Writing 1970-2006: An Assessment'. Journal of Black Studies 38 (3) 388-406.

Galabuzi, G. (2006). Canada's Economic Apartheid: The Social Exclusion of Racialized Groups in the New Century. Toronto: Canadian Scholars' Press.

James, C., Este, D., Bernard, T.W., Benjamin, A., Lloyd, B. \& Turner, T. (2010). Race \& Well-Being: The Lives, Hopes, and Activism of African Canadians. Halifax: Fernwood Publishing.

Lampkin, L. (1985). 'Visible Minorities in Canada' In Abella, R. S. (Ed.), Research Studies of the Commission on Equality in Employment. (pp. 651-683). Ottawa: Supply and Services Canada.

Laryea, A. S. \& Hayfron, E. J. (2006). 'African Immigrants \& the Labor Market: Exploring Career Opportunities, Earning Differentials, \& Job Satisfaction' In Tettey, W. The African Diaspora in Canada: Negotiating Identity and Belonging. Calgary: University of Calgary Press.

Mensah, J. (2010). Black Canadians: History, Experience, Social Conditions. (2 ${ }^{\text {nd }}$ Ed.). Halifax: Fernwood Publishing. 
Porter, J. (1965). The vertical mosaic: an analysis of social class and power in Canada. Toronto: University of Toronto Press.

Saney, I. (1998). 'Canada: The Black Nova Scotian odyssey: A chronology'. Race \& Class 40 (1) 78-91.

Satzewich, V., \& Liodakis, N. (Eds.). (2007). 'Race' and Ethnicity in Canada A Critical Introduction. Oxford: University Press. . (2001). Census of Canada. At http://www12.statcan.ca/english/census01/home/index.cfm. . (2001). Canadian Social Trends 2001 Census. Catalogue no. 11-008. . (2001). Profiles of Ethnic Communities in Canada: The African Community in Canada. Catalogue no. 89-621-XIE - No. 10. August.

. (2007). Immigration in Canada: A Portrait of the Foreign-Born Population, 2006 Census. Catalogue no. 97-557-XIE. December. . (2008). Canada's Ethno cultural Mosaic, 2006 Census. Catalogue no. 97-562-X. April.

Tettey, J.W. \& Puplampu, P.K. (Eds.). (2006). 'Continental Africans in Canada: Exploring a Neglected Dimension of the African-Canadian Experience' In Tettey, J.W. \& Puplampu, P.K. The African Diaspora in Canada: Negotiating Identity and Belonging. (pp. 4-23). Calgary: University of Calgary Press. . (2006). 'Ethnicity \& the Identity of African-Canadians: A Theoretical \& Political Analysis' In Tettey, J.W. \& Puplampu, P.K., The African Diaspora in Canada: Negotiating Identity and Belonging. (pp. 25-48). Calgary: University of Calgary Press.

Tulloch, H. (1975). Black Canadians: A Long Line of Fighters. Toronto: N.C. Press.

Walker, J.W. (1980). A History of Blacks in Canada. Ottawa: Minister of State and Multiculturalism.

Winks, R. (1971). The Blacks in Canada: A History. Montreal: McGill University Press. . (1997). The Blacks in Canada: A History $\left(2^{\text {nd }}\right.$ Ed). Montreal: McGill University Press. 